\title{
PEMAHAMAN KUANTITATIF DASAR DAN PENERAPANNYA DALAM MENGKAJI KETERKAITAN ANTARA BENTUK DAN MAKNA
}

\author{
${ }^{1,2}$ Gede Primahadi Wijaya Rajeg(i) \& ${ }^{1}$ I Made Rajeg(i) \\ ${ }^{1}$ Universitas Udayana, Indonesia \& 2 Monash University, Australia \\ primahadiwijaya@gmail.com \& made_rajeg@unud.ac.id
}

\begin{abstract}
Abstrak
Makalah ini memaparkan pemahaman kuantitatif mendasar, khususnya teknik statistik analitik Chi-Square $\left(\chi^{2}\right)$, dan penerapannya untuk permasalahan linguistik terkait hubungan antara bentuk dan makna. Berdasarkan data dari Indonesian Web as Corpus, makalah ini menggunakan medan leksikal PANAS sebagai contoh untuk mengukur keterkaitan antara pemakaian (non-)metaforis dan bentuk morfosintaksis kata berdasarkan sampel sitiran verba berakar panas, dan kata panas itu sendiri. Analisis $\chi^{2}$ menunjukkan keterkaitan yang sangat signifikan dan kuat antara realisasi morfosintaksis medan leksikal PANAS dan distribusi pemakaian (non-)metaforisnya. Efek keterkaitan yang paling kuat ditunjukkan oleh bentuk inkohatif memanas yang berasosiasi positif dengan pemakaian metaforis, dan bentuk dipanaskan dan panas yang berasosiasi negatif dengan pemakaian metaforis. Temuan ini berimplikasi terhadap adanya ciri semantis dominan terkait wujud morfosintaksis suatu kata, fenomena yang dapat mencerminkan keterkaitan antara bentuk dan makna pada bahasa.
\end{abstract}

Kata kunci: Chi-Square; Linguistik Korpus Kuantitatif; bahasa pemrograman R; metafora; keberpasangan bentuk-dan-makna; medan leksikal PANAS; Bahasa Indonesia

\begin{abstract}
This contribution discusses basic concepts of Chi-Square $\left(\chi^{2}\right)$ test as a kind of analytical statistics and illustrates its application to one of the central issues in linguistics, namely formmeaning relationship. As a case study using Indonesian Web as Corpus from the Sketch Engine, this paper measures the association between morphosyntactic forms of words in the lexical field of PANAS 'hot' and their (non-)metaphorical usages. The $\chi^{2}$ test demonstrates a highly significant and robust association between the morphosyntactic form of words with the root panas 'hot' and their preference for (non-)metaphorical usages. The clear effects are shown by (i) the strong preference of the inchoative form memanas 'to become hot' for metaphorical usage, and (ii) the strong dispreference of dipanaskan 'to be caused to be hot' and panas 'hot' for metaphorical usage. This finding has implication on the predominant semantic trait of words with certain morphosyntactic forms, thus capturing the form-meaning relationship in language.
\end{abstract}

Keywords: Chi-Square; Quantitative Corpus Linguistics; R programming language; metaphors; form-meaning pairing; lexical field of PANAS; Indonesian

\section{PENDAHULUAN ${ }^{1}$}

Memasuki awal abad ke-21, penelitian linguistik umumnya, dan Linguistik Kognitif (LKog) khususnya, semakin gencar bergerak menuju pendekatan kuantitatif menggunakan beragam metode statistik untuk pengolahan data; pergerakan ini diistilahkan dengan "the quantitative turn" (Janda, 2013a; Levshina, 2015, hlm. 2-3). Revolusi kuantitatif ini utamanya dipicu oleh (i) pergeseran teoretis ke arah pendekatan linguistik berdasarkan pemakaian (usage-based

\footnotetext{
${ }^{1}$ Penulis berterima kasih kepada mitra bebestari atas dukungan dan masukan yang baik untuk meningkatkan kualitas makalah ini. Penulisan makalah ini didukung oleh dana penelitian doktoral dari Monash University, Australia yang diberikan kepada Gede Primahadi Wijaya Rajeg: Monash International Postgraduate Research Scholarships (MIPRS) \& Monash Graduate Scholarships (MGS).
} 
linguistics), seperti halnya LKog (Tummers, Heylen, \& Geeraerts, 2005); (ii) ketersediaan sejumlah bank data elektronik pemakaian bahasa (linguistic corpora) yang ukurannya bisa mencapai miliaran bahkan triliunan kata; dan (iii) keberadaan peranti statistik komputasional tak berbayar, utamanya R (R Core Team, 2018), yang semakin lazim di kalangan peneliti bahasa khususnya (Baayen, 2008; Gries, 2013; Janda, 2013a; Levshina, 2015) maupun pakar pengolahan data (data scientists) secara umum (Wickham \& Grolemund, 2017).

Asas pemakaian (usage-based assumption) yang melandasi pendekatan linguistik seperti LKog berimplikasi metodologis terhadap pentingnya keberadaan data empiris dalam kajian kebahasaan (Tummers et al., 2005). Asas pemakaian menekankan bahwa kajian linguistik mesti didasarkan atas data pemakaian nyata, seperti yang diamati pada korpus pemakaian bahasa (Glynn, 2010, hlm. 10; Janda, 2016, hlm. 130), atau yang bisa diperoleh melalui survei dan eksperimen (Tummers et al., 2005, hlm. 229). Asumsi mendasar dari pendekatan linguistik berdasarkan pemakaian ialah pengetahuan dan khasanah kebahasaan penutur dibentuk oleh pemakaian bahasa (Janda, 2016, hlm. 129-131). Selain itu, pengalaman berkelanjutan seorang penutur dalam berkomunikasi dan menerima masukan kebahasaan (linguistic input) mengikutkan tersimpannya informasi kuantitatif terkait konteks pemakaian suatu kata dan kekerapan kemunculan bersama (co-occurrence frequencies) seperangkat kata dan konstruksi (Levshina, 2015, hlm. 3). Kedua asumsi tersebut dapat diuji secara lebih empiris, di antaranya melalui pendekatan linguistik korpus kuantitatif dan metode eksperimental.

Penting untuk dicatat bahwa revolusi kuantitatif bukan berarti mengesampingkan intuisi dalam penelitian kebahasaan (bdk. Janda, 2013a, hlm. 3). Intuisi tetap berperan penting, utamanya dalam (i) memaknai/interpretasi data dan (ii) merumuskan praanggapan, hipotesis, dan permasalahan teoretis dalam linguistik. Ketersediaan bank data dan penerapan metode kuantitatif bertujuan untuk membantu perumusan dan pemaparan permasalahan linguistik secara lebih empiris dan terukur (Stefanowitsch, 2010). Dengan kata lain, salah satu keuntungan dari penerapan metode linguistik korpus kuantitatif adalah informasi kuantitatif yang dapat diolah secara statistik guna mendukung dan/atau mengajukan argumentasi teoretis terkait suatu fenomena kebahasaan. Hasil tersebut selanjutnya akan kembali menjadi hipotesis yang dapat digugurkan atau didukung oleh penelitian empiris selanjutnya. Akan tetapi, menggabungkan permasalahan teoretis dengan pendekatan kuantitatif bukan hal yang mudah (Janda, 2016, hlm. 128). Penyebabnya ialah bahwa perihal teoretis tidak secara gamblang mensyaratkan penerapan metode kuantitatif tertentu, dan analisis kuantitatif tidak selalu menjamin adanya relevansi teoretis. Jadi, peneliti berperan sangat penting dalam merumuskan permasalahan teoretis yang tepat dan dapat dijawab dengan pendekatan kuantitatif (Janda, 2016; Stefanowitsch, 2010; Tummers et al., 2005, hlm. 238).

Makalah ini memberikan contoh sederhana namun mendasar terkait bagaimana pendekatan kuantitatif dapat menerangkan permasalahan teoretis dalam linguistik (Glynn, 2010; Gries, 2013; Janda, 2016, 2013b; Kuznetsova, 2015; Levshina, 2015; Tummers et al., 2005). Salah satu pertanyaan utama, atau "Big Questions" (Janda, 2016, hlm. 128), dalam linguistik ialah hubungan antara bentuk (form) dan makna (meaning) (Kuznetsova, 2015). Pendekatan linguistik seperti LKog memandang bentuk dan makna sebagai kesatuan penting dari bahasa dan dapat dikaji melalui pendekatan kuantitatif (Glynn, 2010; Janda, 2016; Stefanowitsch, 2010). Mengkaji hubungan antara bentuk dan makna berdasarkan asas pemakaian mengikutkan bahwa (i) perbedaan pemakaian suatu bentuk linguistik mengindikasikan perbedaan makna dari bentuk tersebut (periksa Kuznetsova, 2015, hlm. 13-14; Stefanowitsch, 2010, hlm. 368-370), dan (ii) perbedaan bentuk tentunya mencerminkan perbedaan makna (Janda, 2016, hlm. 129).

Menggunakan objek kajian pemakaian (non-)metaforis medan leksikal PANAS dalam Bahasa Indonesia (§2), makalah ini akan menunjukkan bahwa terdapat perbedaan distribusi pemakaian (non-)metaforis berkaitan dengan wujud morfosintaksis medan leksikal PANAS. Kajian serupa telah dilakukan sebelumnya oleh Deignan (2006) dengan data korpus Bahasa Inggris. Deignan mengamati bahwa suatu kata akan cenderung digunakan secara metaforis dalam kelas kata yang 
berbeda dan pola sintaksis tertentu. Misalnya, proporsi pemakaian literal untuk lema blossom secara signifikan lebih tinggi dalam fungsinya sebagai nomina; sebaliknya proporsi pemakaian metaforisnya lebih tinggi ketika berfungsi sebagai verba (Deignan, 2006, hlm. 112). Contoh serupa dalam Bahasa Indonesia dapat ditemui pada verba denominal seperti mengepalai (dari akar nomina kepala) dan menangani (dari akar nomina tangan); kedua verba ini memiliki makna metaforis (mis. mengepalai selalu berarti 'memimpin'), sedangkan akar nominanya masih bisa digunakan baik secara literal untuk mengacu pada anggota badan maupun secara metaforis (mis. kepala negara 'presiden' atau tangan kanan 'orang kepercayaan'). Temuan ini mencerminkan bagaimana makna tertentu (misalnya metaforis dan literal) dapat berkaitan erat dengan ciri morfosintaksis suatu kata (bdk. Janda, 2016, hlm. 129; Kuznetsova, 2015).

Kandungan pokok dari makalah ini terkait permasalahan di atas ialah pemaparan mendasar terhadap pemahaman analisis statistik yang digunakan, mulai dari yang bersifat deskriptif ( $\$ 3.1)$ hingga analitik (inferential/analytical statistics) (\$3.2) (Gries, 2013, Bab 4). Teknik statistik yang dibahas adalah uji signifikansi dengan Chi-Square, yang dilambangkan dengan $\chi^{2}(\$ 3.3)$. Makalah ini juga menyisipkan bagian terkait penggunaan $\mathrm{R}$ untuk melakukan uji statistik $C h i$ Square (\$3.4). Guna menutup bagian Pendahuluan ini, selanjutnya akan dipaparkan alasan dipilihnya Chi-Square $\left(\chi^{2}\right)$ pada makalah ini.

Alasan pertama berkaitan dengan tujuan analitis makalah ini guna mengukur keterkaitan antara dua variabel yang bersifat "kategorikal" (Gries, 2013, hlm. 16-17), yaitu BENTUK (MORFOSINTAKSIS) dan MAKNA. Artinya, kedua variabel tersebut memiliki unsur/terdiri atas kategori dengan ciri berbeda. Misalnya variabel BENTUK terdiri atas beragam bentuk morfosintaksis medan leksikal PANAS (§2). Sementara itu, variabel MAKNA dicirikan atas dua unsur, yaitu LITERAL dan METAFORIS (\$3.2). Chi-Square ialah uji signifikansi statistik yang lazim digunakan untuk mengukur keterkaitan antara dua variabel kategorikal (seperti yang dibahas dalam makalah ini) berdasarkan kekerapan kemunculan suatu variabel kategorikal (mis. makna literal dan/atau metaforis) terhadap variabel yang lain (mis. bentuk morfosintaksis kata) (Gries, 2013, hlm. 178; Janda, 2013a; Levshina, 2015, hlm. 199).

Alasan kedua berkaitan dengan aspek pemahaman kuantitatif secara lebih luas. Dengan mengenali Chi-Square, kita juga akan dapat membangun pemahaman atas sejumlah konsep penting dalam uji signifikansi statistik secara umum. Konsep-konsep tersebut meliputi hipotesis kosong (null hypothesis) dan hipotesis alternatif (alternative hypothesis) (\$3.2); kekerapan riil (observed frequency) dan kekerapan harapan (expected frequency) (\$3.3.1); tingkat signifikansi (significance level) (\$3.2) dan peluang kesalahan (probability of error atau $p$ value) (\$3.3.2). Pemahaman terhadap konsep-konsep tersebut bukan semata-mata untuk membantu peneliti (i) menerapkannya dalam suatu analisis, namun juga, yang tak kalah pentingnya, (ii) memahami tulisan-tulisan lain yang menggunakan uji signifikansi statistik seperti Chi-Square. Sebagai catatan tambahan berdasarkan pengalaman pribadi, penulis pertama kali mulai memahami konsep-konsep mendasar dalam uji signifikansi statistik setelah membaca tutorial Chi-Square oleh Stefanowitsch $(2004)^{2}$. Dengan kata lain, Chi-Square dapat dijadikan sebagai salah satu batu loncatan guna memahami uji signifikansi statistik lainnya untuk jenis variabel berbeda (Gries, 2013).

Berdasarkan atas dua alasan tersebut, makalah ini bertujuan untuk berbagi pemahaman mendasar terhadap uji signifikansi statistik Chi-Square dan menerapkannya terhadap permasalahan linguistik mendasar namun krusial, yaitu hubungan antara bentuk dan makna (Janda, 2016; Kuznetsova, 2015). Selanjutnya, makalah ini diharapkan dapat meningkatkan minat dan wawasan terhadap kajian linguistik Indonesia melalui pendekatan kuantitatif (baik berdasarkan data korpus ataupun eksperimen), yang dewasa ini masih terbilang jarang

\footnotetext{
${ }^{2}$ Pranala untuk tutorial oleh Stefanowitsch (2004) sudah tidak aktif sejak tahun 2012, namun penulis masih menyimpan pindaian PDF laman tersebut.
} 
(beberapa di antaranya, Arka, 2017; Aryawibawa \& Ambridge, 2018; Denistia \& Baayen, 2018; Denistia, Bajestan, \& Baayen, 2018; Moeljadi, 2011, 2014; Musgrave, 2013; G. P. W. Rajeg, 2014, 2016, 2018; G. P. W. Rajeg \& Rajeg, 2017, 2019; G. P. W. Rajeg, Denistia, \& Musgrave, 2018; G. P. W. Rajeg, Denistia, \& Rajeg, 2018; Rajeg, 2014; Siahaan, 2011).

\section{DATA}

Korpus yang menjadi sumber data makalah ini ialah Indonesian Web as Corpus (IWaC) (109.281.359 juta kata) (Kilgarriff et al., 2014). IWaC tersedia daring melalui layanan korpus berbayar Sketch Engine (SE) (https://www.sketchengine.eu/). Penulis mencari 100 sampel sitiran acak pemakaian kata-kata dengan akar kata panas, yaitu panas itu sendiri, kemudian bentuk turunannya sebagai kata kerja, utamanya memanas, memanaskan, dipanaskan, dipanasi dan memanasi; gugusan kata tersebut tercakup dalam medan leksikal PANAS. Penulis menyadari terdapat beberapa bentuk lain yang tidak diikutkan dalam makalah ini, misalnya berpanaspanasan, sepanas, terpanas, kepanasan, dan lainnya. Namun, hal tersebut dianggap tidak menghalangi tujuan utama makalah ini untuk memperkenalkan pemahaman dasar atas uji signifikansi Chi-Square dan penerapannya terhadap salah satu kajian linguistik. Pencarian sampel sitiran untuk kata yang diteliti dilakukan dalam rentang waktu 30 hari percobaan akun gratis untuk SE di pertengahan tahun 2013. Tabel 1 menampilkan lima sitiran acak dari total 458 sitiran medan leksikal PANAS yang dikaji, dengan tampilan konteks di sebelah kiri (left) dan kanan (right) dari kata kunci (node).

\section{Tabel 1 Lima sitiran konkordansi acak medan leksikal PANAS}

\begin{tabular}{|c|c|c|c|c|}
\hline id & left & node & right & use \\
\hline 7173 & $\begin{array}{r}\text { sitas ( kegemukan ) akibat } \\
\text { gesekan lapisan lemak yang }\end{array}$ & & $\begin{array}{l}\text { testis, dan kelompok pria yang dalam } \\
\text { pekerjaannya duduk ter }\end{array}$ & lit \\
\hline 3197 & $\begin{array}{r}\text { ransel yang ditingkatkan . } \\
\text { Dikarenakan }\end{array}$ & & $\begin{array}{l}\text { yang dihasilkan dari perlengkapan } \\
\text { RGM - } 79 \text { SC }\end{array}$ & lit \\
\hline 74310 & $\begin{array}{r}\text { n-bahan lain yang dapat } \\
\text { terbakar untuk }\end{array}$ & 1 & $\begin{array}{l}\text { air . Pemanasan air ini juga dapat } \\
\text { ditempuh denga }\end{array}$ & lit \\
\hline 23156 & $\begin{array}{r}\text { Bambang Trihatmojo dan } \\
\text { Halimah kembali }\end{array}$ & memanas & $\begin{array}{l}\text { Pascapertengkarannya beberapa waktu } \\
\text { lalu, tern }\end{array}$ & met \\
\hline 53466 & $\begin{array}{r}\text { dengan baik sebagai satu } \\
\text { senjata untuk }\end{array}$ & memanaskan & $\begin{array}{l}\text { rapat dengan pidato yang hebat . Pidato } \\
\text { bertu }\end{array}$ & met \\
\hline
\end{tabular}

Kolom id merupakan penanda sitiran yang dikeluarkan dari pencarian konkordansi di SE.

Kemudian, kolom use merupakan variabel yang menandai apakah baris sitiran untuk suatu kata kunci menunjukkan pemakaian "lit(eral)" atau "met(aforis)". Peneliti menemukenali kedua pemakaian tersebut secara manual dengan melihat konteks pemakaian kata kunci pada tiap-tiap sitiran berdasarkan Metaphor Identification Procedure (MIP) (Pragglejaz Group, 2007), sembari menandainya melalui Excel. Pemakaian literal kata-kata tersebut secara umum mengacu pada pemakaiannya pada ranah suhu yang bersifat badaniah (periksa tiga baris sitiran pertama pada Tabel 1). Sementara itu, pemakaian metaforisnya menunjukkan pemetaan unsur suhu badaniah ke ranah yang lebih abstrak, seperti emosi atau intensitas suatu keadaan (seperti pada dua baris terakhir pada Tabel 1). Sitiran ganda (duplicates) secara manual ditandai dan tidak diikutkan dalam analisis kuantitatif selanjutnya. Semua analisis statistik, termasuk tabel dan grafik, dan penulisan makalah ini dilakukan melalui RStudio menggunakan $R$ Markdown Notebook dan dua modul R pendukung, yaitu tidyverse (https://www.tidyverse.org) (Wickham \& Grolemund, 2017) dan $v c d$ (Meyer, Zeileis, \& Hornik, 2017; Zeileis, Meyer, \& Hornik, 2007). Data sitiran yang dikaji dan berkas $R$ Markdown Notebook tersedia dengan akses terbuka melalui tautan berikut: https://github.com/gederajeg/pemahaman_kuantitatif_chisquare. 


\section{HASIL DAN PEMBAHASAN}

Bagian ini meliputi tiga pokok pembahasan. Hal pertama merupakan analisis statistik yang bersifat deskriptif (§3.1). Hal kedua mencakup pemahaman terkait signifikansi statistik dan hipotesis ilmiah (\$3.2), serta uji signifikansi statistik menggunakan Chi-Square (§3.3). Hal terakhir ialah cara melakukan Chi-Square menggunakan R (§3.4).

\subsection{Memahami data melalui tabel dan grafik}

Pemaparan deskriptif terkait distribusi kategori yang dicakup variabel BENTUK MORFOSINTAKSIS (panas, memanas, memanasi, dsb.) dan MAKNA (lit(eral) dan met(aforis)) dapat diawali dengan tabulasi kekerapan silang (crosstabulation) seperti pada Tabel 2 berikut.

\section{Tabel 2 Kekerapan riil antara kategori MAKNA (baris) dan BENTUK MORFOSINTAKSIS} (kolom)

\begin{tabular}{lrrrrrrr} 
& dipanasi & dipanaskan & memanas & memanasi & memanaskan & panas & total \\
\hline lit & 18 & 96 & 17 & 29 & 76 & 85 & 321 \\
met & 2 & 3 & 80 & 15 & 22 & 15 & 137 \\
total & 20 & 99 & 97 & 44 & 98 & 100 & 458
\end{tabular}

Tampak bahwa, misalnya, pemakaian literal bentuk pasif dipanasi (18 sitiran) berjumlah lebih sedikit dibandingkan dengan bentuk aktif memanasi (29). Namun, yang perlu diperhatikan ialah jumlah keseluruhan sampel dari tiap-tiap kata berbeda. Misalnya, pencarian 100 sampel untuk bentuk dipanasi di SE hanya menghasilkan total 20 sitiran, demikian halnya dengan memanasi (44 sitiran). Untuk dapat melakukan perbandingan yang seimbang, sebaiknya nilai kekerapan disamakan terlebih dahulu (Levshina, 2015, hlm. 70). Penyamaannya bisa dalam bentuk (i) kekerapan relatif (relative frequency atau proportion dalam bentuk bilangan desimal dengan rentangan antara 0 sampai 1) (Periksa Tabel 3 berikut), (ii) persentase, atau (iii) kekerapan berdasarkan suatu bilangan acuan (misalnya kekerapan per 100 atau 1000 sitiran) yang dikenal dengan istilah normalised frequency (Gries, 2010, hlm. 271).

Tabel 3 Kekerapan relatif/proporsi antara kategori MAKNA dan BENTUK MORFOSINTAKSIS

\begin{tabular}{lrrrrrr} 
& dipanasi & dipanaskan & memanas & memanasi & memanaskan & panas \\
\hline lit & 0.9 & 0.97 & 0.18 & 0.66 & 0.78 & 0.85 \\
met & 0.1 & 0.03 & 0.82 & 0.34 & 0.22 & 0.15
\end{tabular}

Kini dapat diperhatikan bahwa proporsi pemakaian literal dari total sitiran dipanasi relatif lebih tinggi (yaitu 0.9 atau 90\%) dibandingkan dengan memanasi (sekitar 0.66 atau 65.91\%). Proporsi makna literal dan metaforis untuk suatu kata diperoleh dengan membagi kekerapan suatu jenis makna dengan total sitiran kata tersebut. Sebagai contoh, penghitungan proporsi makna literal dipanasi adalah $\frac{18}{20}$, yaitu 0.9 , dan proporsi metaforisnya adalah $\frac{2}{20}$, yaitu 0.1 . Informasi pada Tabel 2 dan Tabel 3 dapat dipahami secara lebih intuitif melalui tampilan visual diagram batang seperti Gambar 1, yang dihasilkan menggunakan modul ggplot2 (Wickham, 2016) sebagai bagian dari tidyverse. 


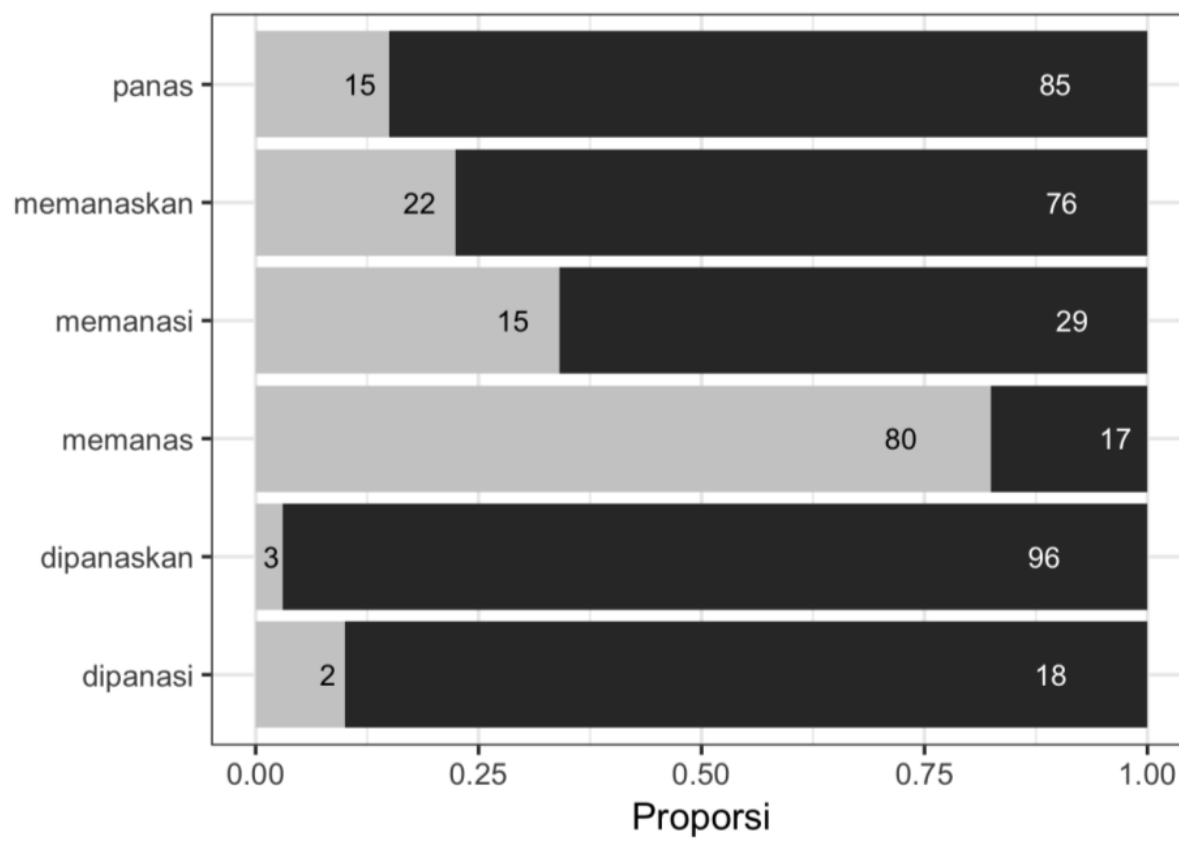

pemakaian

Angka di dalam grafik batang menunjukkan kekerapan riil

Gambar 1 Proporsi sitiran literal dan metaforis terkait bentuk morfosintaksis medan leksikal PANAS

Terlihat jelas bahwa verba inkohatif memanas memiliki proporsi sitiran metaforis yang paling tinggi dibandingkan bentuk verba lainnya, yang didominasi oleh pemakaian literal. Ulasan deskriptif ini dapat mengindikasikan peluang adanya hubungan antara morfosintaksis kata berakar sama dan makna tertentu yang cenderung disampaikannya. Pertanyaan selanjutnya adalah bagaimana cara menentukan secara empiris bahwa perbedaan distribusi makna dari sampel pemakaian medan leksikal PANAS ini penting dan bukanlah suatu kebetulan? Dengan kata lain, bagaimana kita mengetahui bahwa distribusi tersebut signifikan secara statistik? Berkaitan dengan pertanyaan ini, $\$ 3.2$ berikut mengulas secara ringkas pemahaman istilah signifikansi statistik.

\subsection{Signifikansi statistik dan hipotesis ilmiah}

Signifikansi statistik merujuk pada pertanyaan apakah perbedaan distribusi, yang diamati dalam sampel, hanya merupakan suatu kebetulan (based on chance) (Gries, 2013, hlm. 28;

Stefanowitsch, 2004). Distribusi dikatakan signifikan secara statistik apabila peluang (likelihood atau probability) bahwa distribusi tersebut dianggap acak/manasuka (random) lebih kecil dari $5 \%$; nilai ini diistilahkan dengan tingkat signifikansi $\left(p_{\text {critical }}\right)$ dan umumnya ditulis dalam bentuk desimal, yaitu 0.05 (hasil dari 5/100) (Gries, 2013, hlm. 27, 2014, hlm. 317; Janda, 2013a, hlm. 9-10).

Jika dikaitkan dengan contoh kajian makalah ini, signifikansi statistik merujuk pada peluang ditemukannya perbedaan persebaran pemakaian literal dan metaforis terkait bentuk morfosintaksis medan leksikal PANAS (seperti pada Tabel 2) apabila benar adanya bahwa seharusnya tidak ada perbedaan persebaran makna literal dan metaforis terkait realisasi morfosintaksis dari medan leksikal PANAS tersebut. Hal yang penting untuk diperhatikan ialah signifikansi statistik dari distribusi suatu fenomena kebahasaan tidak akan pernah menjamin signifikansinya secara linguistik, dalam arti, tidak menunjukkan karakteristik penting suatu sistem kebahasaan (bdk. Gries, 2013, hlm. 28). Namun, jika distribusi suatu fenomena kebahasaan tidak signifikan secara statistik, maka hal menarik sehubungan dengan pola kebahasaan tersebut mungkin tidak akan terangkat (periksa Stefanowitsch, 2004). 
Analisis statistik terkait uji signifikansi melibatkan dua hipotesis yang diuji berdasarkan data, yaitu (i) hipotesis kosong (null hypothesis) (selanjutnya disebut $\mathrm{H}_{0}$ ) dan (ii) hipotesis alternatif (alternative hypothesis) $\left(\mathrm{H}_{1}\right)$ (Gries, 2014, hlm. 317; Levshina, 2015, hlm. 8-9). $\mathrm{H}_{0}$ umumnya menyatakan distribusi setara/acak, atau ketidakterkaitan di antara variabel yang dikaji. $\mathrm{H}_{1}$ sebaliknya menggangap adanya keterkaitan di antara variabel berdasarkan perbedaan distribusinya (periksa Gries, 2013, hlm. 10-14). Berikut dipaparkan dua hipotesis yang berkaitan dengan makalah ini:

- $\quad \mathrm{H}_{0}$ (hipotesis kosong): Rasio pemakaian literal dan metaforis tidak berbeda sehubungan dengan beragam bentuk morfosintaksis kata-kata pada medan leksikal PANAS. Artinya, bentuk intransitif memanas, transitif memanaskan dan bentuk pasif-nya dipanaskan seharusnya memiliki distribusi pemakaian literal dan metaforis yang setara dalam sampel.

- $\quad \mathrm{H}_{1}$ (hipotesis alternatif): Rasio pemakaian literal dan metaforis berbeda sehubungan dengan beragam bentuk morfosintaksis kata-kata pada medan leksikal PANAS tersebut. Dengan kata lain, diasumsikan bahwa terdapat kaitan antara bentuk morfosintaksis kata pada medan leksikal PANAS dengan proporsi makna literal dan metaforis terkait pemakaian kata tersebut dalam korpus.

Hal yang tidak diperinci dari $\mathrm{H}_{1}$ terkait perbedaan distribusi ini ialah arah perbedaannya. Yaitu, apakah misalnya memanaskan, dibandingkan dengan memanasi, lebih sering (atau lebih jarang) digunakan secara metaforis (dibandingkan secara literal) dalam sampel korpus. Inti yang disampaikan oleh $\mathrm{H}_{1}$ adalah adanya perbedaan distribusi. Arah dari perbedaan distribusi tersebut tidak dapat diperinci untuk saat ini karena belum ditemukannya kajian sebelumnya dalam Bahasa Indonesia yang melihat kaitan antara bentuk morfosintaksis kata berakar sama dengan makna literal dan/atau metaforis yang disampaikan dalam pemakaian kata tersebut. Meskipun demikian, perlu diketahui bahwa Siahaan (2015) telah melakukan kajian metafora konseptual terkait pemakaian medan leksikal TEMPERATUR dalam Bahasa Indonesia, namun dengan menggabungkan semua realisasi morfosintaksis guna mencerminkan suatu jenis temperatur. Misalnya, pemakaian metaforis kepanasan, memanaskan, panas, digabungkan ke dalam sitiran metaforis konsep PANAS tanpa melihat perbedaan dan kaitannya dengan bentuk morfosintaksis kata-kata tersebut. Jadi, hasil analisis dalam makalah ini, yang tidak meliputi pengelompokan metafora konseptualnya, akan memberikan asumsi awal terhadap perbedaan distribusi pemakaian literal dan metaforis terhadap bentuk morfosintaksis kata-kata tersebut, yang selanjutnya dapat diujikan kembali menggunakan sampel yang lebih besar, medan leksikal lainnya, dan jenis korpus yang berbeda. Lebih lanjut, tujuan utama dari uji signifikansi statistik adalah untuk tidak mencoba membuktikan kebenaran $\mathrm{H}_{1}$, melainkan mencoba menggugurkan asumsi yang diajukan oleh $\mathrm{H}_{0}$ (periksa Gries, 2013, hlm. 26-29 untuk ulasan lebih dalam).

Terdapat sejumlah metode uji signifikansi statistik. Yang umum digunakan untuk menguji signifikansi distribusi variabel kategorikal seperti pada Tabel 2 adalah Chi-Square test ${ }^{3}$ (Gries, 2013, hlm. 178-189; Janda, 2013a, hlm. 9-14; Levshina, 2015, Bab 9; Stefanowitsch, 2004). Yang dimaksud dengan "variabel kategorikal" (atau yang juga dikenal dengan variabel nominal) adalah variabel yang unsur-unsurnya memiliki ciri yang berbeda. Pada kasus ini, misalnya, variabel MAKNA mengandung unsur dengan ciri berbeda, yaitu LITERAL dan METAFORIS. Jenis variabel lainnya adalah variabel ordinal (mis. RENDAH, SEDANG, TINGGI) dan variabel rasio/numerik (mis. panjang kata berdasarkan jumlah suku kata atau panjang suatu kalimat berdasarkan jumlah kata, dsj.), yang kaitan di antara unsurnya dapat dihubungkan dengan kalimat komparatif (mis. kata X dua kali lebih panjang dibandingkan kata $\mathrm{Y}$ berdasarkan jumlah suku katanya) (periksa Gries, 2013, hlm. 16-17, untuk ulasan lebih dalam).

\footnotetext{
${ }^{3}$ Unsur chi dilafalkan ky, yang berima sama dengan high atau fly dalam Bahasa Inggris (Stefanowitsch, 2004).
} 


\subsection{Uji signifikansi Chi-Square $\left(\chi^{2}\right)$}

\subsubsection{Kekerapan Harapan dan Kekerapan Riil}

Untuk mengetahui apakah suatu distribusi muncul secara acak/kebetulan, hal yang pertamatama mesti diketahui adalah bagaimana distribusi yang diharapkan muncul secara acak berdasarkan $\mathrm{H}_{0}$, atau yang dikenal dengan istilah kekerapan harapan (expected frequency, selanjutnya disingkat menjadi $\mathrm{F}_{\mathrm{e}}$ ) (Gries, 2013, hlm. 180; Janda, 2013a, hlm. 9; Levshina, 2015, hlm. 210). Dalam hal ini, $F_{\mathrm{e}}$ adalah distribusi yang diharapkan muncul apabila benar adanya bahwa tidak ada hubungan antara bentuk morfosintaksis medan leksikal PANAS dengan proporsi pemakaian literal dan metaforis (yaitu, $\mathrm{H}_{0}$ ) (periksa §3.2). Tes $\chi^{2}$ melibatkan perbandingan antara $\mathrm{F}_{\mathrm{e}}$ dan kekerapan yang diamati pada sampel data, yang disebut dengan kekerapan riil (observed frequency, disingkat $\mathrm{F}_{\mathrm{o}}$ ). Berikut adalah rumus umum untuk menghitung $\mathrm{F}_{\mathrm{e}}$ tiap-tiap sel, yaitu $E_{i j}$, di dalam tabel layaknya Tabel 2 (bdk. Levshina, 2015, hlm. 211):

$$
E_{i j}=\frac{S_{i} \cdot S_{j}}{N}
$$

$S_{i}$ menunjukkan kekerapan marjinal total (marginal frequency) baris $i, S_{j}$ menunjukkan kekerapan total kolom $j$, dan $N$ adalah total pengamatan dalam sampel; jadi, $\mathrm{F}_{\mathrm{e}}$ tiap-tiap sel ditentukan berdasarkan kekerapan total tiap-tiap kolom dan baris (ditandai dengan huruf miring pada Tabel 4, yang merupakan pengulangan Tabel 2).

Tabel 4 Kekerapan riil antara kategori MAKNA dan BENTUK MORFOSINTAKSIS

\begin{tabular}{llllllll} 
& dipanasi & dipanaskan & memanas & memanasi & memanaskan & panas & total \\
\hline lit & 18 & 96 & 17 & 29 & 76 & 85 & 321 \\
met & 2 & 3 & 80 & 15 & 22 & 15 & 137 \\
total & 20 & 99 & 97 & 44 & 98 & 100 & 458
\end{tabular}

Sebagai contoh, penghitungan $\mathrm{F}_{\mathrm{e}}$ untuk sel pada pêrsimpangan baris lit dan kolom dipanasi adalah $\frac{20 \cdot 321}{458}$, yaitu 14.017. Sebagai contoh tambahan, $\mathrm{F}_{\mathrm{e}}$ untuk sel pada persimpangan met dan memanas adalah $\frac{97 \cdot 137}{458}$, yaitu 29.015. Tabel 5 menunjukkan nilai $\mathrm{F}_{\mathrm{e}}$ untuk semua kombinasi kategori MAKNA dan BENTUK MORFOSINTAKSIS; nilai $\mathrm{F}_{\mathrm{e}}$ tersebut telah dibulatkan menjadi 3 angka desimal setelah koma.

Tabel 5 Kekerapan harapan berdasarkan $\mathbf{H}_{\mathbf{0}}$ antara kategori MAKNA dan BENTUK
MORFOSINTAKSIS
\begin{tabular}{lrrrrrr} 
dipanasi & dipanaskan & memanas & memanasi & memanaskan & panas \\
\hline lit & 14.017 & 69.386 & 67.985 & 30.838 & 68.686 & 70.087 \\
met & 5.983 & 29.614 & 29.015 & 13.162 & 29.314 & 29.913
\end{tabular}

Nilai total tiap-tiap kolom dan baris pada Tabel 5 akan sama dengan nilai total tiap-tiap baris dan kolom pada Tabel 4. Misalnya, total penjumlahan nilai $\mathrm{F}_{\mathrm{e}}$ untuk kolom memanas ialah 97 (yaitu $67.985\left[\mathrm{~F}_{\mathrm{e}} \mathrm{lit}\right]+29.015\left[\mathrm{~F}_{\mathrm{e} \text { met }}\right]=97$ ), jumlah yang sama untuk memanas pada Tabel 4 .

Setelah mengetahui bagaimana $F_{e}$ diperoleh, mungkin muncul pertanyaan mengapa $F_{e}$ dihitung sedemikian rupa. Penalarannya ialah sebagai berikut (periksa Gries, 2013, hlm. 182183; Stefanowitsch, 2004). Kekerapan total tiap-tiap baris dan kolom adalah nilai yang tetap (fixed) dan demikian adanya (given) berdasarkan sampel; nilai tersebut menunjukkan (i) total sitiran literal dan metaforis dalam sampel, dan (ii) total sitiran sampel untuk tiap-tiap bentuk morfosintaksis medan leksikal PANAS. Apabila nilai total tersebut terdistribusi secara acak untuk keduabelas persimpangan baris dan kolom dalam Tabel 4, yaitu met+dipanasi, lit+dipanasi, met+dipanaskan, lit+dipanaskan, dst., maka distribusinya harus proporsional, yang artinya 
dapat dipahami sebagai berikut. Terdapat 321 sitiran (dari total 458 sitiran) medan leksikal PANAS yang menunjukkan pemakaian literal dan 137 sisanya merupakan sitiran metaforis. Dengan kata lain, $70.09 \%$ dari total 458 sitiran medan leksikal PANAS yang dikaji digunakan secara literal (yaitu, $\frac{321}{458} \cdot 100$ ) dan $29.91 \%$-nya digunakan secara metaforis (yaitu, $\frac{137}{458} \cdot 100$ ). Apabila persebaran pemakaian literal dan metaforis untuk keenam kata medan leksikal PANAS tersebut didasarkan atas kebetulan/bersifat acak (based on chance), persebarannya harus proporsional dengan persentase pemakaian literal dan metaforis secara umum seperti yang sudah dijelaskan sebelumnya. Artinya, $70.09 \%$ dari total sitiran untuk panas, memanas, memanasi, dst. seharusnya bermakna literal dan $29.91 \%$ dari total sitiran untuk tiap-tiap kata tersebut seharusnya bermakna metaforis. Sebagai contoh, $70.09 \%$ dari total 20 sitiran untuk dipanasi yang seharusnya bermakna literal adalah sekitar 14.017 sitiran (yaitu, $\frac{70.09}{100} \cdot 20$ ), nilai yang persis muncul pada sel untuk lit+dipanasi pada Tabel 5 di atas; pembaca dipersilakan untuk memeriksa sekaligus mencoba penghitungan serupa untuk sel lainnya.

Dengan membandingkan nilai tiap-tiap sel pada Tabel 5 dan Tabel 4, kita dapat mengetahui kombinasi mana yang muncul lebih sering atau jarang dari yang diharapkan (periksa pula Gambar 2 pada §3.3.2). Misalnya, memanas lebih sering dari yang diharapkan untuk digunakan secara metaforis. Tahap selanjutnya (\$3.3.2) ialah menghitung kadar perbedaan $F_{o}$ terhadap $F_{e}$ untuk mengetahui bahwa kekerapan riil yang diamati dalam sampel bukanlah suatu kebetulan.

\subsubsection{Kontribusi sel terhadap nilai statistik $\chi^{2}$ dan tingkat signifikansi}

Uji statistik $\chi^{2}$ mensyaratkan bahwa $80 \%$ dari nilai $\mathrm{F}_{\mathrm{e}}$ pada tiap sel suatu tabel kekerapan harus lebih besar atau sama dengan 5 (Gries, 2013, hlm. 166; periksa juga Levshina, 2015, hlm. 212). Apabila persyaratan tersebut tidak terpenuhi, atau nilai dalam tabulasi silang terlalu kecil, disarankan menggunakan uji signifikansi Fisher-Yates Exact test (Levshina, 2015, hlm. 213214). Tabel 5 menunjukkan bahwa semua (100\%) sel memiliki $\mathrm{F}_{\mathrm{e}}$ lebih besar dari 5. Untuk mendapatkan nilai statistik $\chi^{2}$, kita mesti menghitung nilai kontribusi tiap-tiap sel terhadap $\chi^{2}$ ("contribution to chi-squared" (Gries, 2013, hlm. 168)) yang dirumuskan sebagai berikut (Levshina, 2015, hlm. 212; Stefanowitsch, 2004):

$$
\text { Pearson } \chi^{2}=\sum_{i=1}^{r} \sum_{j=1}^{c} \frac{\left(O_{i j}-E_{i j}\right)^{2}}{E_{i j}}
$$

Rumus tersebut menunjukkan bahwa nilai $\chi^{2}$ merupakan hasil penjumlahan dari pemangkatan perbedaan $F_{o}$ dengan $F_{e}$ yang dibagi dengan $F_{e}$ untuk tiap-tiap sel. Sebagai contoh, nilai kontribusi terhadap $\chi^{2}$ untuk sel lit+dipanasi adalah $\frac{(18-14.017)^{2}}{14.017}$, yaitu 1.131; ulangi penghitungan serupa untuk sel yang lain untuk selanjutnya dijumlahkan menjadi nilai statistik $\chi^{2}$, yang hasilnya adalah $\chi^{2}=179.31$. Pertanyaan berikutnya ialah apakah nilai $\chi^{2}$ ini mengindikasikan perbedaan/penyimpangan (deviation) yang cukup besar oleh $\mathrm{F}_{\mathrm{o}}$ terhadap $\mathrm{F}_{\mathrm{e}}$ sehingga distribusi riil $\mathrm{F}_{\mathrm{o}}$ pada Tabel 4 dapat dikatakan bukan suatu kebetulan?

Peranti statistik pada umumnya menggunakan nilai $\chi^{2}$ guna mengukur peluang kesalahan (probability of error), yang juga dikenal dengan sebutan p-value (Gries, 2013, hlm. 27, 2014, hlm. 317). P-value menunjukkan peluang ditemukannya (i) distribusi dalam sampel (yaitu, $\mathrm{F}_{\mathrm{o}}$ dalam Tabel 4), dan juga (ii) penyimpangannya dari $\mathrm{F}_{\mathrm{e}}$ yang diharapkan oleh $\mathrm{H}_{0}$, ketika $\mathrm{H}_{0}$ dianggap benar. Apabila peluang ini lebih kecil dari tingkat signifikansi 5\% (\$3.2) mengingat $\mathrm{H}_{0}$ dianggap benar, maka (i) distribusi yang diamati dalam sampel dapat dikatakan signifikan secara statistik, yaitu tidak muncul berdasarkan suatu kebetulan, dan (ii) kita dapat menyangkal asumsi dari $\mathrm{H}_{0}$ dengan menunjukkan bahwa terdapat perbedaan distribusi, yang tidak bisa dikatakan sebagai suatu kebetulan, antara dua atau lebih variabel (Gries, 2013, hlm. 27; Levshina, 2015, hlm. 12). Penyangkalan terhadap $\mathrm{H}_{0}$ ini tidak berarti bahwa $\mathrm{H}_{1}$ atau efek perbedaan yang ditemukan benar adanya karena masih terdapat probabilitas/peluang distribusi 
tersebut muncul secara kebetulan, meskipun sangat kecil (Gries, 2014). Sebelum adanya komputer, cara klasik untuk menentukan tingkat signifikansi suatu distribusi ialah membandingkan nilai $\chi^{2}$ yang diperoleh berdasarkan sampel (yaitu $\chi^{2}=179.31$ ) dengan tabel nilai $\chi^{2}$ seperti yang ditunjukkan pada Tabel 6 (Gries, 2013, hlm. 184).

Tabel 6 Nilai $\chi^{2}$ untuk tingkat signifikansi $\left(p_{\text {critical }}\right)=0.05(5 \%), 0.01(1 \%)$, dan 0.001 $(0.1 \%)$ untuk $1 \leq d f \leq 5$

\begin{tabular}{lllll}
$d f$ & $p=0.05$ & $p=0.01$ & $p=0.001$ & $\ldots$ \\
\hline 1 & 3.841 & 6.635 & 10.828 & $\ldots$ \\
2 & 5.991 & 9.21 & 13.816 & $\ldots$ \\
3 & 7.815 & 11.345 & 16.266 & $\ldots$ \\
4 & 9.488 & 13.277 & 18.467 & $\ldots$ \\
5 & 11.07 & 15.086 & 20.515 & $\ldots$ \\
$\ldots$ & $\ldots$ & $\ldots$ & $\ldots$ & $\ldots$
\end{tabular}

Kolom $d f$ menunjukkan degree of freedom (Levshina, 2015, hlm. 12) dari suatu tabel distribusi. $D f$ secara singkat mengacu pada jumlah nilai yang dapat berubah (vary). Rumus mengukur nilai $d f$, dan nilai $d f$ untuk tabel distribusi pada makalah ini, adalah sebagai berikut:

$$
d f=(\mathrm{N} \text { baris }-1) \cdot(\mathrm{N} \mathrm{kolom}-1)=(2-1) \cdot(6-1)=5
$$

Nilai $d f=5$, dengan kekerapan marjinal total yang tetap, menunjukkan bahwa hanya 5 sel dari Tabel 4 yang nilainya dapat diubah tanpa mengubah jumlah kekerapan marjinalnya (bdk. Levshina, 2015, hlm. 12).

Jadi, untuk mengetahui signifikansi distribusi pemakaian literal dan metaforis dari medan leksikal PANAS, kita mulai dengan baris yang menunjukkan nilai $d f=5$ dan memeriksa apakah nilai $\chi^{2}=179.31$ yang diperoleh lebih besar dari nilai $\chi^{2}$ yang ada pada baris tersebut pada Tabel 6. Terlihat jelas bahwa nilai $\chi^{2}$ yang diperoleh dalam sampel hampir sekitar sembilan kali lebih besar dari nilai $\chi^{2}$ yang ada pada kolom signifikansi $0.1 \%$ (yaitu kolom $p=0.001$ dengan $\chi^{2}=20.515$ ). Hal ini menunjukkan bahwa terdapat peluang yang sangat kecil (lebih kecil dari $0.1 \%$ atau $p<0.001$ ) untuk menemukan perbedaan distribusi antara bentuk morfosintaksis dan tipe makna pada Tabel 4 apabila (i) perbedaan tersebut dianggap sebagai suatu kebetulan, dan (ii) tidak ada keterkaitan antara bentuk morfosintaksis medan leksikal PANAS dan makna (non)metaforis.

Nilai statistik lain yang mesti dilaporkan selain p-value ialah kadar efek (effect size) (Janda, 2013a, hlm. 11). Berbeda dengan $p$-value yang menunjukkan peluang acak tidaknya kemunculan suatu distribusi, kadar efek menunjukkan seberapa penting dan kuat efek hubungan/korelasi di antara kedua variabel. Untuk tabel kekerapan dengan jumlah baris dan/atau kolom di atas dua, kadar efek yang dilaporkan ialah Cramér's V (Gries, 2013, hlm. 185-186; Janda, 2013a, hlm. 10; Levshina, 2015, hlm. 217). Rentangan nilai Cramér's V ialah antara 0 (tidak ada hubungan) dan 1 (hubungan sempurna): (i) 0.1 adalah ambang batas untuk kadar efek kecil yang dapat dilaporkan; (ii) 0.3 untuk kadar efek cukup (moderate); dan (iii) 0.5 untuk kadar efek besar/kuat (robust) (Janda, 2013a, hlm. 10-11; bdk. Levshina, 2015, hlm. 209). Berikut ini adalah rumus penghitungan Cramér's V (Gries, 2013, hlm. 186):

$$
\text { Cramér's } V=\sqrt{\frac{\chi^{2}}{N \cdot\left(\min \left[N_{\text {baris }}, N_{\text {kolom }}\right]-1\right)}}=\sqrt{\frac{179.31}{458 \cdot(2-1)}}=0.626
$$

Jadi, hasil analisis statistik Chi-Square menunjukkan perbedaan distribusi yang sangat signifikan dan keterkaitan yang kuat antara bentuk morfosintaksis kata dalam medan leksikal PANAS dan pemakaian literal dan metaforisnya $\left(N=458 ; \chi^{2}=179.31 ; d f=5 ; p<0.001\right.$; 
Cramér's $V=0.626$ ) (bdk. Deignan, 2006). Gambar 2, yang dihasilkan melalui modul $\mathrm{R} v c d$, merupakan bagan asosiasi yang secara lebih jelas menunjukkan arah dan besar nilai penyimpangan $F_{o}$ terhadap $F_{e}$ tiap-tiap sel terkait dua variabel yang dikaji (Gries, 2013, hlm. 188; Levshina, 2015, hlm. 220).
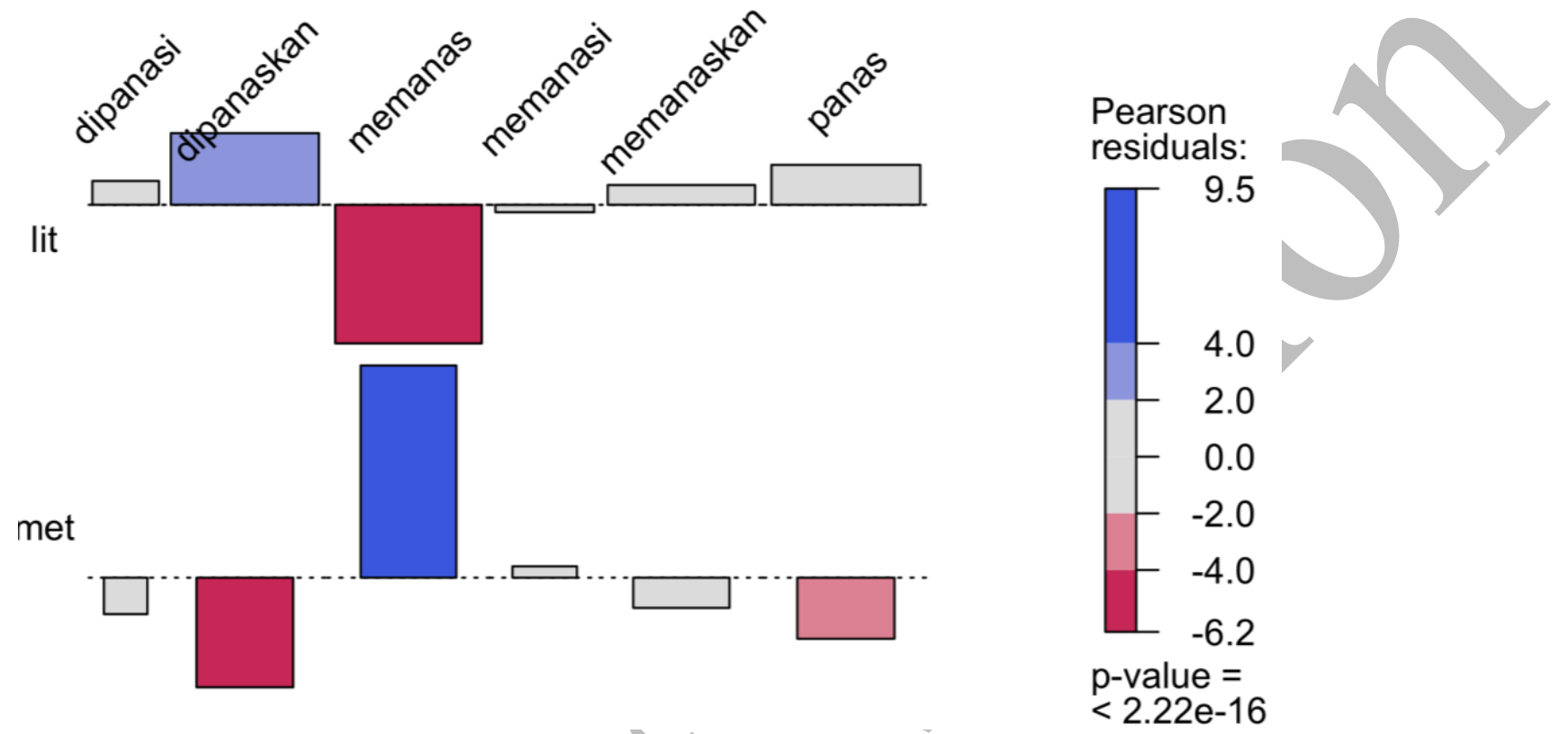

Gambar 2 Bagan asosiasi kategori MAKNA dan BENTUK MORFOSINTAKSIS medan leksikal PANAS

Nilai Pearson residuals menunjukkan besar nilai efek perbedaan antara kekerapan riil $\left(\mathrm{F}_{\mathrm{o}}\right)$ dan kekerapan harapan $\left(\mathrm{F}_{\mathrm{e}}\right)$ tiap-tiap sel (Gries, 2013, hlm. 187-188; Levshina, 2015, hlm. 218-219). Semakin besar nilai absolut residual tiap-tiap sel, semakin besar penyimpangan $F_{o}$ terhadap $F_{e}$, dan semakin besar kontribusi sel tersebut terhadap nilai statistik $\chi^{2}$ keseluruhan. Efek yang berkontribusi kuat terhadap keterkaitan signifikan antara variabel MAKNA dan BENTUK MORFOSINTAKSIS ditunjukkan melalui dua unsur: (i) panjang-pendeknya diagram batang yang dapat menjulang ke atas (residual positif, yaitu $F_{o}>F_{e}$ ) atau terbalik ke bawah (residual negatif, yaitu $F_{o}<F_{e}$ ); dan (ii) kegelapan warna diagram batang tiap-tiap sel (semakin gelap warnanya, semakin besar efek perbedaan $\mathrm{F}_{\mathrm{o}}$ terhadap $\mathrm{F}_{\mathrm{e}}$ ) (bdk. Levshina, 2015, hlm. 220). Berdasarkan informasi ini,tampak bahwa verba inkohatif memanas adalah satu-satunya bentuk yang berasosiasi paling kuat dengan pemakaian metaforis dibandingkan pemakaian literalnya. Sementâra itu, bentuk pasif kausatif dipanaskan dan bentuk akar panas berasosiasi negatif dengan pemakaian metaforis dalam sampel; dipanaskan juga satu-satunya bentuk yang berasosiasi cukup kuat dengan pemakaian literal dalam sampel. Hasil ini menunjukkan bahwa (i) makna tertentu bisa memiliki kecenderungan (atau rasio yang lebih tinggi) untuk diungkapkan dalam bentuk morfosintaksis kata tertentu, dan (ii) keberpasangan bentuk-danmakna tersebut dapat ditentukan secara lebih terukur dengan merumuskannya secara kuantitatif (bdk. Janda, 2016).

\subsection{Uji signifikansi $\chi^{2}$ dengan $R$}

Pemaparan rinci dan bertahap sebelumnya terkait $\chi^{2}$ dan uji signifikansi secara umum penting untuk dipahami sebelum prosesnya dipermudah dengan bantuan peranti komputasional seperti R. Nukilan kode berikut menunjukkan tahapan melakukan analisis $\chi^{2}$ dengan R. Pertama-tama, data mentah makalah ini, yaitu berkas panas_raw.txt yang disimpan dalam folder data, mesti dimuat ke dalam $\mathrm{R}$ dan disimpan ke dalam objek bernama panas (lihat kembali Tabel 1). Data ini selanjutnya digunakan untuk membuat tabulasi kekerapan seperti Tabel 4. 


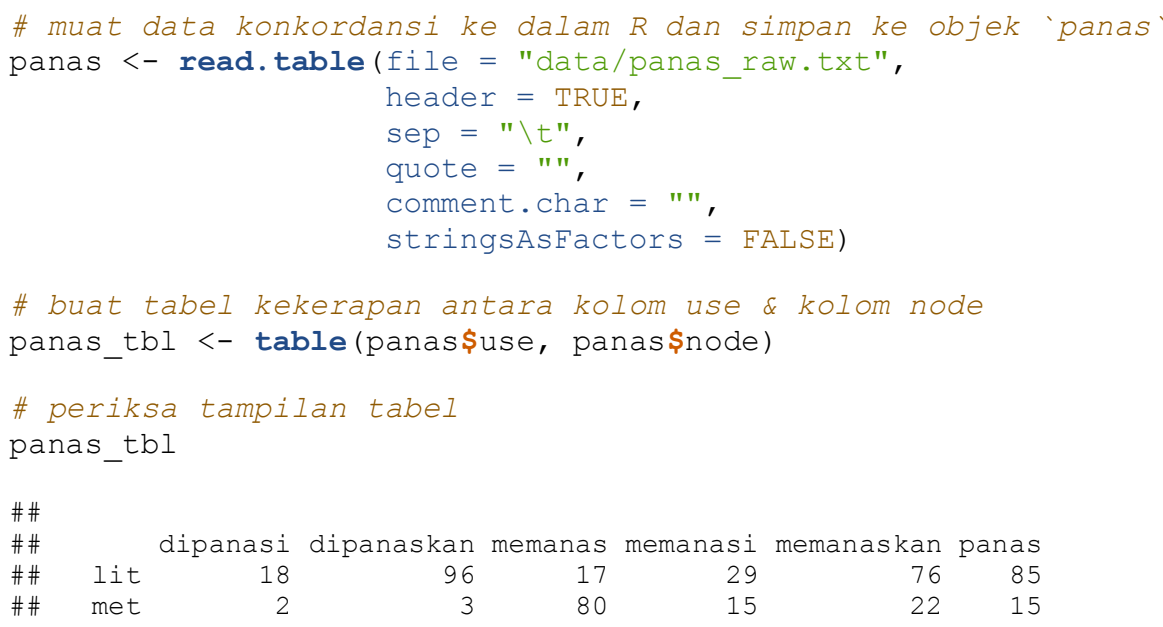

Analisis $\chi^{2}$ pada $\mathrm{R}$ dilakukan dengan fungsi chisq.test() dengan masukan berupa tabulasi data panas_tbl yang dihasilkan sebelumnya.

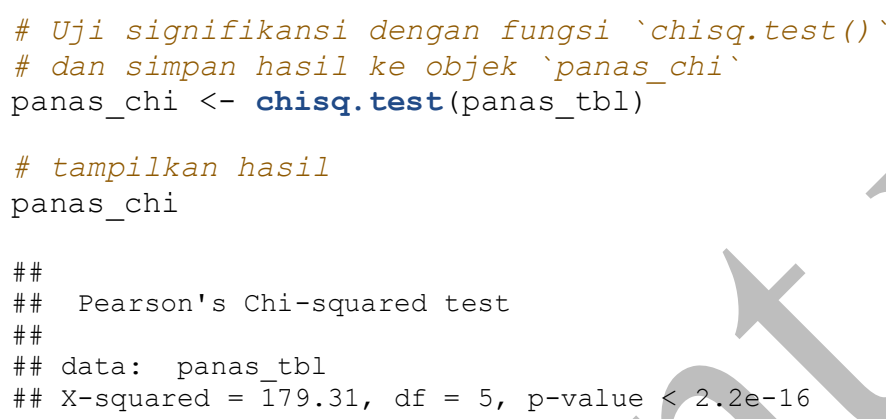

Luaran dari chisq.test () terdiri dari beberapa unsur, di antaranya (i) statistic yang menunjukkan nilai $\chi^{2}$; (ii) parameter untuk nilai $d f$; (iii) p.value, yaitu $p<2.2 \mathrm{e}-16^{4}$ pada tampilan hasil di atas; (iv) observed (atau $\mathrm{F}_{\mathrm{o}}$ ); (v) expected (atau $\mathrm{F}_{\mathrm{e}}$ ); (vi) residuals, yang merupakan nilai Pearson residuals (Gambar 2). Isi dari tiap-tiap unsur tersebut dapat diperoleh menggunakan tanda mata uang dolar (\$) sebagai berikut:

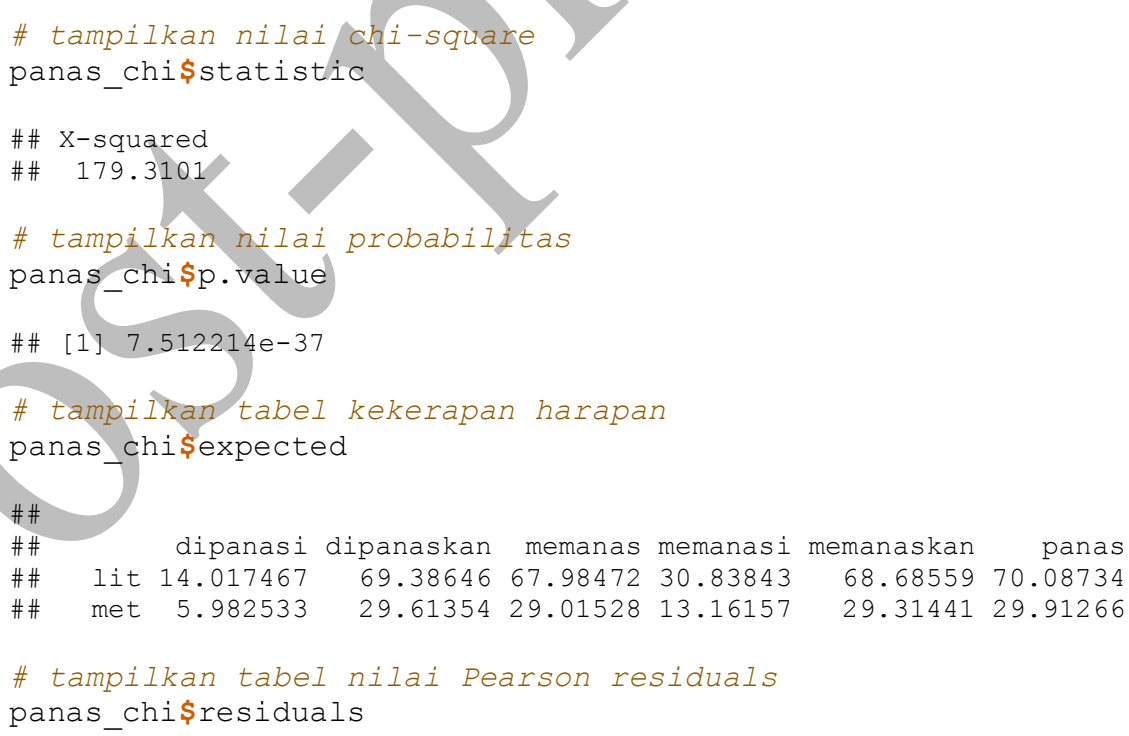

${ }^{4}$ Nilai 2.2e-16 merupakan tampilan ilmiah untuk bilangan desimal 0.00000000000000022 yang mengandung 15 angka 0 setelah koma dan diikuti angka 22. 


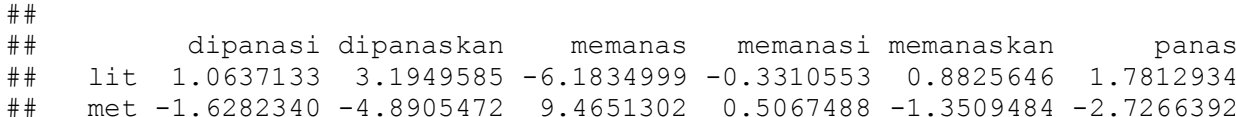

Nilai kontribusi terhadap $\chi^{2}$ untuk tiap-tiap sel merupakan hasil pangkat 2 dari nilai Pearson residuals tiap-tiap sel:

\# hitung kontribusi terhadap chi-square

panas chi\$residuals^2

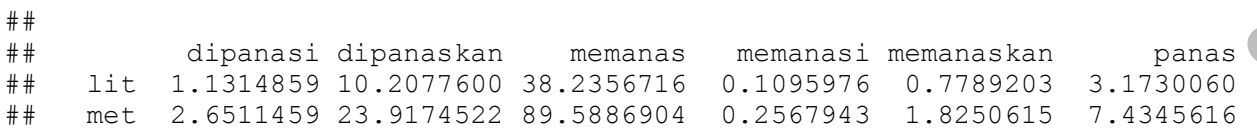

Selanjutnya, nilai kadar efek Cramér's $V$ dihitung dengan kode berikut:

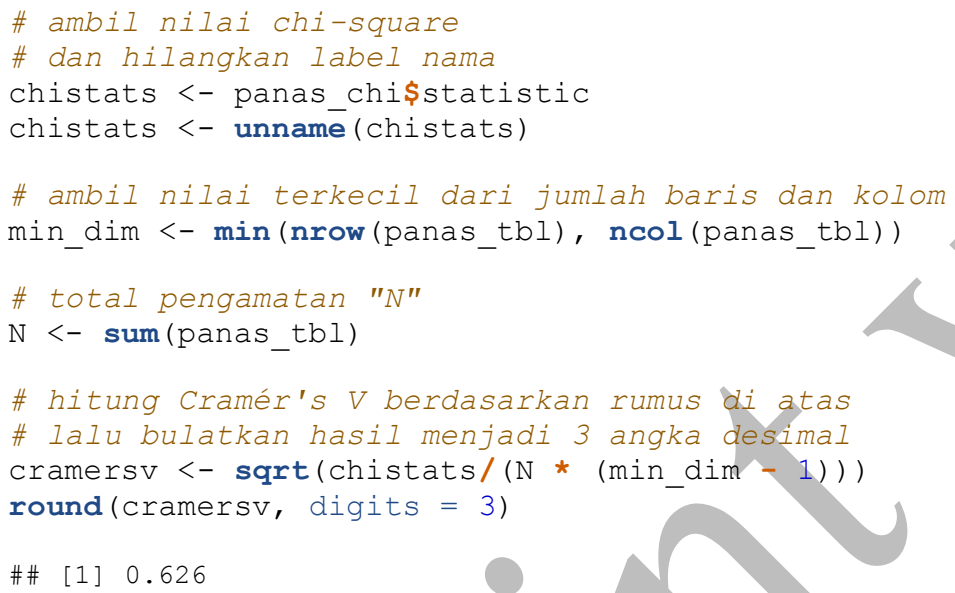

\section{PENUTUP}

Makalah ini telah mengulas pemahaman kuantitatif mendasar atas uji signifikansi Chi-Square dalam mengkaji hubungan antara bentuk dan makna pada kasus distribusi makna (non)metaforis medan leksikal PANAS dalam Bahasa Indonesia. Ditemukan bahwa terdapat hubungan yang sangat signifikan dan kuat antara realisasi morfosintaksis medan leksikal PANAS dan makna literal dan metaforisnya (\$3.3.2). Dengan menggunakan metode kuantitatif, ditunjukkan pula bahwa hubungan antara bentuk dan makna bukan merupakan soal hitam-putih, namun bersifat gradien, dan sifat ini sebaiknya dicirikan berdasarkan distribusi statistik. Contohnya, meskipun memanas bisa digunakan dengan makna literal, namun bentuk inkohatif ini lebih condong dari yang diharapkan untuk digunakan secara metaforis; sebaliknya bentuk pasif kausatif dipanaskan jauh lebih lazim digunakan secara literal (Gambar 2). Kecenderungan statistik seperti ini akan sulit untuk diungkap dengan mengandalkan metode introspeksi.

Pertanyaan terkait mengapa bentuk-bentuk tersebut memiliki perilaku semantis yang berbeda belum dapat dijawab kali ini. Setidaknya, hasil analisis ini dalam Bahasa Indonesia mendukung temuan serupa dalam Bahasa Inggris (Deignan, 2006) terkait hubungan bentuk gramatikal suatu kata dengan perbedaan proporsi pemakaian metaforis dan literalnya. Kajian ini juga telah (i) memberikan bukti empiris terkait asumsi bahwa bentuk yang berbeda memiliki batasan semantis yang berbeda ( $(1)$, dan (ii) menunjukkan bagaimana asumsi tersebut dapat dirumuskan berdasarkan distribusi kuantitatif dalam korpus.

Penerapan uji statistik analitik (analytical statistics) seperti pada makalah ini mengijinkan peneliti untuk menentukan tingkat keumuman (generalisation) temuan berdasarkan sampel terhadap keseluruhan populasi, dalam hal ini semua populasi pemakaian medan leksikal PANAS yang dikaji, khususnya pada jenis teks daring yang mendasari korpus IWaC. Namun, jenis teks dari korpus yang digunakan merupakan salah satu faktor yang pada kesempatan ini belum dapat 
dipertimbangkan dengan seksama. Hasil berbeda dari makalah ini bisa muncul jika menggunakan korpus dengan tema berbeda (misalnya novel); ini adalah pertanyaan empiris yang juga mesti dibuktikan melalui penelitian berbeda. Selain perihal korpus, keterkaitan signifikan dan kuat yang ditemukan juga terbatas pada kata-kata dari satu jenis medan leksikal semantik, yaitu PANAS; kajian sistematis terhadap jenis medan leksikal lainnya masih perlu dilakukan. Terlepas dari batasan-batasan tersebut, makalah ini sedikitnya telah mencontohkan bagaimana salah satu pertanyaan mendasar dalam linguistik dapat dikaji menggunakan metode kuantitatif, khususnya Chi-square. Mengingat peta kelinguistikan setakat ini bergerak ke arah komputasional, kuantitatif, dan mengandalkan data tekstual yang besar (big data), maka pemahaman terhadap metode kuantitatif dan peranti komputasional, seperti R, menjadi investasi berharga bagi generasi peneliti bahasa abad ke- 21 .

\section{DAFTAR PUSTAKA}

Arka, I. W. (2017). The core-oblique distinction in some Austronesian languages of Indonesia and beyond. Linguistik Indonesia, 35(2), 101-144. doi:10.26499/li.v35i2.58

Aryawibawa, I. N., \& Ambridge, B. (2018). Is Syntax Semantically Constrained? Evidence From a Grammaticality Judgment Study of Indonesian. Cognitive Science, 1-14. doi:10.1111/cogs.12697

Baayen, R. H. (2008). Analyzing linguistic data: A practical introduction to statistics using $R$. Cambridge, UK ; New York: Cambridge University Press.

Deignan, A. (2006). The grammar of linguistic metaphors. In A. Stefanowitsch \& S. T. Gries (Eds.), Corpus-based approaches to metaphor and metonymy (pp. 106-122). Berlin: Mouton de Gruyter.

Denistia, K., \& Baayen, R. H. (2018). Pe-and PeN-: A corpus-based analysis in allomorphy. In K. E. Sukamto (Ed.), Prosiding Kongres Internasional Masyarakat Linguistik Indonesia (KIMLI) 2018 (pp. 179-183). Universitas Papua, Manokwari: Masyarakat Linguistik Indonesia (MLI). Retrieved from https://osf.io/fnh7y/

Denistia, K., Bajestan, E. S., \& Baayen, R. H. (2018, September). A semantic vector model for the Indonesian prefixes pe-and peN-. Presented at the 11th International Conference on the Mental Lexicon, Edmonton, Alberta, Canada. Retrieved from https://mentallexicon2018.ca/wpcontent/uploads/2018/09/MenLex2018_AbstractBooklet.pdf

Glynn, D. (2010). Corpus-driven cognitive semantics: Introduction to the field. In Dylan Glynn \& Kerstin Fischer (Eds.), Quantitative methods in cognitive semantics: Corpus-driven approaches (pp. 1-41). Berlin: Mouton de Gruyter.

Gries, S. T. (2010). Useful statistics for corpus linguistics. In Aquilino Sánchez \& Moisés Almela (Eds.), A mosaic of corpus linguistics: Selected approaches (pp. 269-291). Frankfurt am Main: Peter Lang. Retrieved from http://www.linguistics.ucsb.edu/faculty/stgries/research/2010_STG_UsefulStats4CorpL ing_MosaicCorpLing.pdf

Gries, S. T. (2013). Statistics for linguistics with R: A practical introduction (2nd ed.). Berlin: Mouton de Gruyter.

Gries, S. T. (2014). Basic significance testing. In R. J. Podesva \& D. Sharma (Eds.), Research Methods in Linguistics (1st ed., pp. 316-336). Cambridge University Press. doi:10.1017/CBO9781139013734.017

Janda, L. A. (2013a). Quantitative methods in Cognitive Linguistics: An introduction. In L. A. Janda (Ed.), Cognitive Linguistics: The quantitative turn (pp. 1-32). Berlin: Mouton de Gruyter.

Janda, L. A. (2016). Linguistic profiles: A quantitative approach to theoretical questions. Język I Metoda, 127-145. Retrieved from http://www.ejournals.eu/pliki/art/6710/

Janda, L. A. (Ed.). (2013b). Cognitive linguistics: The quantitative turn. Berlin: Mouton de Gruyter.

Kilgarriff, A., Baisa, V., Bušta, J., Jakubíček, M., Kovvář, V., Michelfeit, J., ... Suchomel, V. (2014). The Sketch Engine: Ten years on. Lexicography, 1, 7-36. 
Kuznetsova, J. (2015). Linguistic profiles: Going from form to meaning via statistics. Berlin: de Gruyter Mouton.

Levshina, N. (2015). How to do Linguistics with R: Data exploration and statistical analysis. John Benjamins Publishing Company.

Meyer, D., Zeileis, A., \& Hornik, K. (2017). Vcd: Visualizing categorical data.

Moeljadi, D. (2011). Possessive verbal predicate constructions in Indonesian. Tokyo University Linguistic Papers, 31, 117-133. Retrieved from http://compling.hss.ntu.edu.sg/who/david/papers/TULIP31_davidmoeljadi.pdf

Moeljadi, D. (2014). Usage of Indonesian possessive verbal predicates: A statistical analysis based on storytelling survey. Tokyo University Linguistic Papers, 35, 155-176. Retrieved from http://compling.hss.ntu.edu.sg/who/david/papers/TULIP35_davidmoeljadi.pdf

Musgrave, S. (2013). Functional categories in the syntax and semantics of Malay. NUSA, 55, 135-152. Retrieved from http://hdl.handle.net/10108/74330

Pragglejaz Group. (2007). MIP: A method for identifying metaphorically used words in discourse. Metaphor and Symbol, 22(1), 1-39.

R Core Team. (2018). R: A language and environment for statistical computing. Vienna, Austria: R Foundation for Statistical Computing. Retrieved from https://www.Rproject.org/

Rajeg, G. P. W. (2014). Metaphorical profiles of five Indonesian quasi-synonyms of ANGER: Multiple distinctive collexeme analysis. In Proceedings of the International Congress of the Linguistic Society of Indonesia 2014 (pp. 165-170). Bandar Lampung, Sumatra, Indonesia: Masyarakat Linguistik Indonesia (MLI). doi:10.4225/03/58578ddba1fd2

Rajeg, G. P. W. (2016). Exploring the semantics of near-synonyms via metaphorical profiles: A quantitative corpus-based study of Indonesian words for HAPPINESS. In Proceedings of the International Congress of The Linguistic Society of Indonesia (pp. 261-265). Universitas Udayana, Bali-Indonesia: Masyarakat Linguistik Indonesia (MLI) \& Universitas Udayana. doi: $10.4225 / 03 / 5913 \mathrm{aec} 719240$

Rajeg, G. P. W. (2018). Happyr: The accompanying R package for Rajeg's (2018) PhD thesis titled "Metaphorical profiles and near-synonyms: A corpus-based study of Indonesian words for Happiness" (Version 0.1.0), doi:10.5281/zenodo.1436331

Rajeg, G. P. W., \& Rajeg, I. M. (2017). Mempertemukan morfologi dan linguistik korpus: Kajian konstruksi pembentukan kata kerja [per-+Ajektiva] dalam Bahasa Indonesia. In I. N. Sudipa \& M. S. Satyawati (eds.), Rona Bahasa: Buku persembahan kepada Prof. Dr. Aron Meko Mbete memasuki masa purnatugas (pp. 288-327). Denpasar, Bali, Indonesia: Swasta Nulus. doi:10.4225/03/5a0627de02453

Rajeg, G. P. W., \& Rajeg, I. M. (2019). Analisis Koleksem Khas dan potensinya untuk kajian kemiripan makna konstruksional dalam Bahasa Indonesia. Etika Bahasa: Buku Persembahan Menapaki Usia Pensiun I Ketut Tika. forthcoming. doi:10.31227/osf.io/uwzts

Rajeg, G. P. W., Denistia, K., \& Musgrave, S. (2018, May). Semantic vector space model and the usage patterns of Indonesian denominal verbs with meN-, meN- -Kan, and meN- -i affixes. Presented at the Twenty-Second International Symposium on Malay/Indonesian Linguistics (ISMIL 22), The University of California, Los Angeles. doi:10.4225/03/5acffc60eb649

Rajeg, G. P. W., Denistia, K., \& Rajeg, I. M. (2018). Working with a linguistic corpus using R: An introductory note with Indonesian negating construction. Linguistik Indonesia, 36(1), 1-36. doi:10.4225/03/5a7ee2ac84303

Rajeg, I. M. (2014). Metafora spesifik emosi Bahasa Indonesia: Kajian linguistik korpus. In Proceedings of the International Congress of the Linguistic Society of Indonesia 2014 (pp. 209-213). Bandar Lampung, Sumatra, Indonesia: Masyarakat Linguistik Indonesia (MLI). Retrieved from https://lib.atmajaya.ac.id/default.aspx?tabID=61\&src=a\&id=278166 
Siahaan, P. (2011). HEAD and EYE in German and Indonesian figurative uses. In Z. A. Maalej $\&$ N. Yu (Eds.), Embodiment via Body Parts: Studies from various languages and cultures (pp. 93-114). Amsterdam/Philadelphia: John Benjamins Publishing Company.

Siahaan, P. (2015). Why is it not cool? Temperature terms in Indonesian. In M. KoptjevskajaTamm (Ed.), The Linguistics of Temperature (pp. 666-699). Amsterdam: John Benjamins Publishing Company.

Stefanowitsch, A. (2004). Quantitative thinking for corpus linguists [Tutorial]. Retrieved August 4, 2011, from http://www-user.uni-bremen.de/ anatol/qnt/qnt_dist.html

Stefanowitsch, A. (2010). Empirical cognitive semantics: Some thoughts. In Dylan Glynn \& Kerstin Fischer (Eds.), Quantitative methods in cognitive semantics: Corpus-driven approaches (pp. 355-380). Berlin: Mouton de Gruyter.

Tummers, J., Heylen, K., \& Geeraerts, D. (2005). Usage-based approaches in Cognitive Linguistics: A technical state of the art. Corpus Linguistics and Linguistic Theory, 1(2), 225-261.

Wickham, H. (2016). Ggplot2: Elegant graphics for data analysis. Springer-Verlag New York. Retrieved from http://ggplot2.org

Wickham, H., \& Grolemund, G. (2017). $R$ for Data Science. Canada: O'Reilly. Retrieved from http://r4ds.had.co.nz/

Zeileis, A., Meyer, D., \& Hornik, K. (2007). Residual-based shadings for visualizing (conditional) independence. Journal of Computational and Graphical Statistics, 16(3), $507-525$. 